\title{
Castleman Hastalığı: Laparoskopik Yaklașımla Tedavi Edilen Pararenal Alanda Nadir Bir Retroperitoneal Kitle
}

\author{
Castleman's Disease: A Rare Retroperitoneal Mass In The Pararenal Space Treated With \\ Laparoscopic Approach
}

Uygar Miçooğulları', Asım Özayar³, Ali Fuat Atmaca²

1 University of Health and Science, Tepecik Training and Research Hospital, Department of Urology, Izmır, Turkey

2 Yildirim Beyazit University, Faculty of Medicine, Department of Urology, Ankara, Turkey

3 Ankara City Hospital, Department of Urology, Ankara, Turkey

Gelis tarihi (Submitted): 30.11 .2019

Kabul tarihi (Accepted): 20.04.2020

Yazıșma / Correspondence Uygar Miçooğulları

Sağlık Bilimleri Üniversitesi,

Tepecik Eğitim ve Araştırma Hastanesi, Üroloji Kliniği,

Yenişehir, Gaziler Cad. No: 468, 35020

Konak / İzmir / Türkiye

E mail: uygarmico@hotmail.com

Gsm: +90543588 8989

\section{ORCID}

U.M. 0000-0003-4729-6104

A.O. $\quad 0000-0002-5302-1927$

A.F.A. $0000-0002-0794-2135$

\section{(c) (1) \$}

$\mathrm{Bu}$ eser Creative Commons AttfGayriticari 4.0 Uluslararassı Lisansı ile lisanslanmıștır.

\section{Özet}

Unicentric Castleman Hastalığı (UCD), etiyolojisi bilinmeyen nadir bir hastalıktır. UCD, lokalize lenfoid doku proliferasyonu ve interfoliküler hipervaskülarite ile karakterizedir. Pararenal alanda, diğer tümörleri taklit edebilen nadir görülen bir kitledir. Bu vakada kliniğimizde laparoskopik yaklaşımla tedavi edilen retroperitoneal UCD’yi sunuyoruz.

Anahtar Kelimeler: castleman hastalığ hiyalin vasküler varyantı, benign tümör, laparoskopi
Abstract

Unicentric Castleman's Disease (UCD) is a rare disorder with unknown etiology. UCD is characterized by a localized lymphoid tissue proliferation and interfollicular hypervascularity. It is a rarely seen mass in the pararenal space, which can mimic other tumors. In this case, we present a retroperitoneal UCD which is treated with laparoscopic approach in our clinic.

Keywords: unicentric castleman's disease, hyaline vascular variant, benign neoplasm 


\section{INTRODUCTION}

Castleman's disease (CD) is defined as angiofollicular lymphoid hyperplasia. It is a rare and clinically benign disease. The estimated incidence of $\mathrm{CD}$ is 0.001 $0.05 \%[1]$.

The histopathological types of $\mathrm{CD}$ are hyaline vascular, plasma cell and mixed varieties, respectively [2]. It usually reveals in two ways clinically; unicentric or multicentric CD. Although it is a rare mass in the pararenal space, it can be easily confused with a retroperitoneal mass, especially an adrenal neoplasm [3]. Differential diagnosis is important because of different treatment modalities and disease prognosis. The definitive diagnosis can only be made via surgical pathology due to difficulty of preoperative diagnosis [4]. We report a retroperitoneal $C D$ case which is treated with laparoscopic approach in our clinic.

\section{CASE REPORT}

A 47 years-old female patient presented with back pain on right side and abdominal discomfort. Abdominal Magnetic Resonance Imaging (MRI) was reported as; a $37 \times 25 \times 20 \mathrm{~mm}$ solid mass lesion with significant restricted diffusion at right renal hilus level (Fig. 1). The lesion was isointense with the kidney in the T1A and T2A sequences. Haemogram test, kidney functions, adrenal hormone level, and other blood test results were normal. She had no disease history or family history. In thorax computed thomography and abdominal MRI there was no another lesion. Mass resection was indicated due to the patient's young age and the difficulty of obtaining definitive diagnosis. Laparoscopic resection of the mass with en bloc dissection was done. Laparoscopic view showed a yellow tumor was found in front of the renal pedicle.

The dissection of mass was challenging, because of its high vascularity and close location of the right renal pedicle. The tumor $(4 \times 3 \times 2 \mathrm{~cm})$ was completely removed from the inferior port place (Fig .2). Pathological examination was reported as; hyaline vascular variant of CD (Fig.3). Concentric hyalinized vascular proliferation at the center and around it concentric lymphocyte clustering similar to onion skin was observed.

Operation time was 140 minutes with minimal blood loss. The patient was discharged from hospital on postoperative day 2 , without any complications.

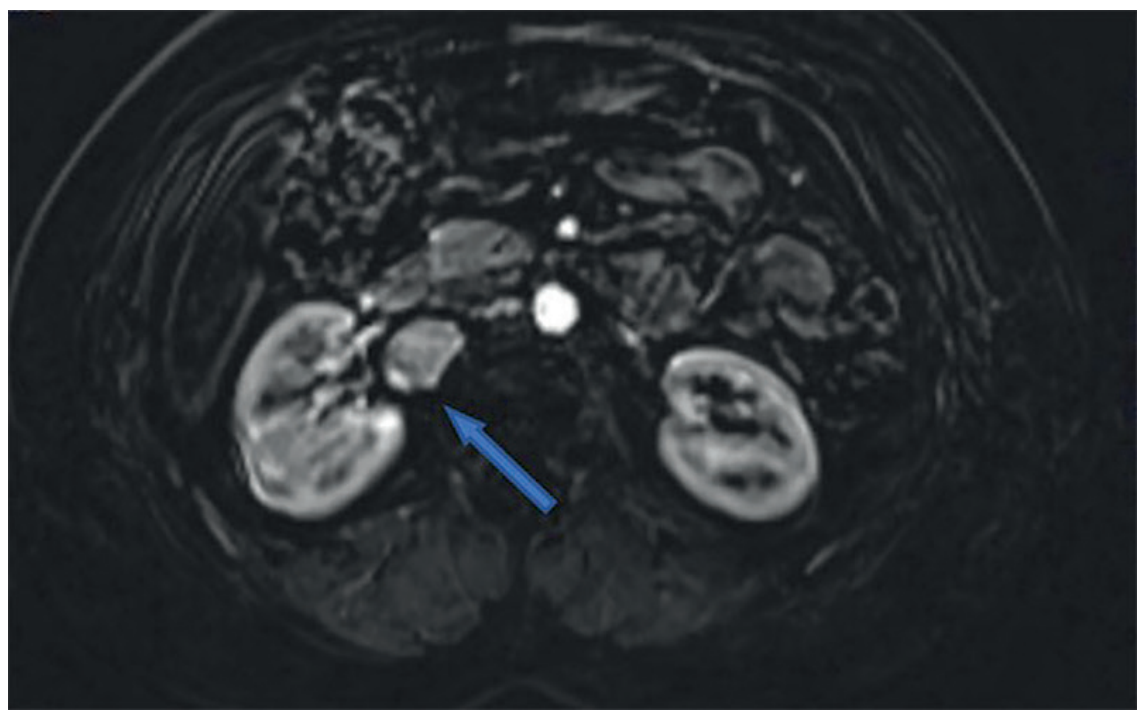

Figure 1. Preoperative axial MRI scan with intravenous contrast showed $3 \mathrm{~cm}$ mass located at the level of the right renal hilus. 


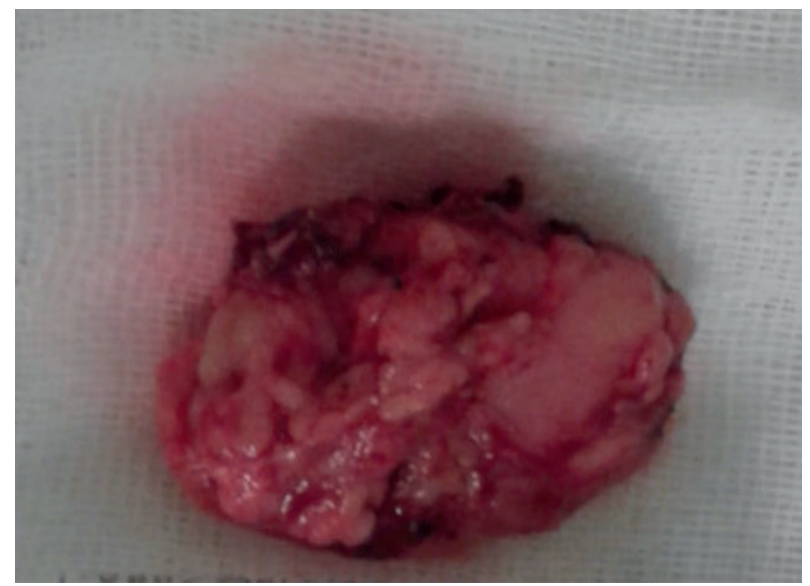

Figure 2. The resected specimen was measured $4 \times 3 \times 2 \mathrm{~cm}$.

\section{DISCUSSION}

Castleman's disease(CD) is a rare disorder of unknown etiology characterized by a localized lymphoid tissue proliferation and interfollicular hypervascularity. There was no association with UCD and infection or malignancy. It consists of $72 \%$ unicentric hyaline variant, $18 \%$ unicentric plasma cell variant and $10 \%$ multicentric plasma variant[2]. The etiology is unknown however; abnormal immunity, immunodeficiency, chronic inflammation may be related to CD. Interleukin 6 (IL-6); plays a major role in inducing lymphocyte differentiation, proliferation and angiogenesis. [2-4-5]. Multicentric Castleman's disease (MCD) is a systemic disease. Weight loss, fever, fatigue, peripheral lymphadenopathy and hepatosplenomegaly can be seen with $\operatorname{MCD}[3,5]$. It is associated with human herpes virus 8 (HHV-8) and human immunodeficiency virus (HIV). It is believed that HHV-8 produces a viral homolog of IL-6 that activates IL-6 signaling pathways [5]. MCD may also be associated with malignancies such as Kaposi's sarcoma, lymphomas and POEMS syndrome[2-5].

$\mathrm{CD}$ can be easily confused with an adrenal neoplasm. Diagnosis can only be confirmed with postoperative pathology [2]. In all types of Castleman disease, surgery is required for differential diagnosis[6]. Our patient presented with back pain on right side and abdominal discomfort. Abdominal MRI was reported as; a $37 \times 25 \times 20 \mathrm{~mm}$ solid mass lesion with significant re-

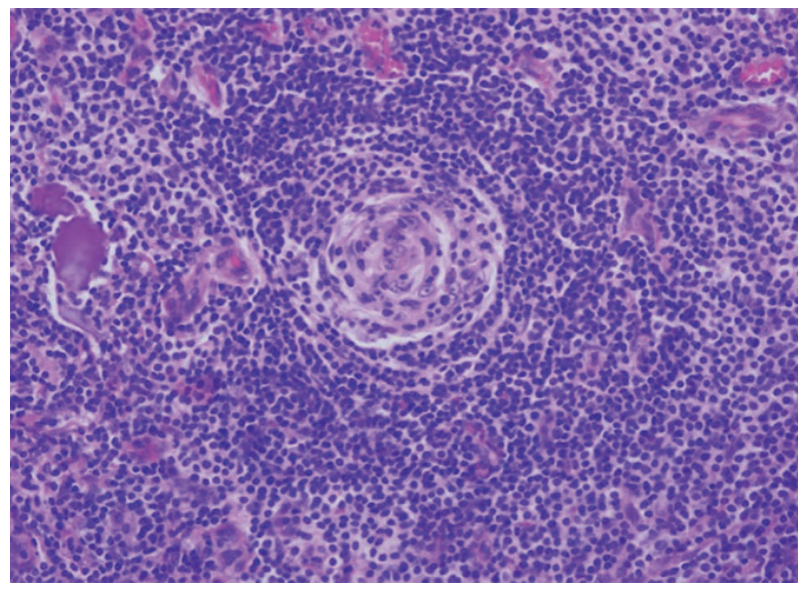

Figure 3. Concentric hyalinized vascular proliferation at the center and around it concentric lymphocyte clustering similar to onion skin.

stricted diffusion at right renal hilus level (Fig. 1). The lesion was isointense with the kidney in the T1 A and T2A sequences. Due to its high vascularity and close proximity to the right renal pedicle; we did not plan to take a biopsy. Haemogram test and direct microscopy of serum cells was normal. No other pathology was observed in imaging tests. Therefore, lymphoma was not considered at first. Mass resection was indicated due to the patient's young age and the difficulty of obtaining definitive diagnosis.

Laparoscopic resection of the mass with en bloc dissection was done. Pathological examination is reported as hyaline vascular variant of CD Concentric hyalinized vascular proliferation at the center and around it concentric lymphocyte clustering similar to onion skin. After resection a leukemia / lymphoma panel was then made and gave a negative result.

\section{CONCLUSION}

Surgical resection is curative and can be safely performed with laparoscopic procedures. In this case, the retroperitoneal region was easily reached by laparoscopic visualization and it allowed us more comfortable dissection and resection of the retroperitoneal mass. In all types of Castleman disease, surgery is required for differential diagnosis. The laparoscopic approach is cheap, safe and minimally invasive method for treatment of retroperitoneal CD. 


\section{Informed Consent}

Patient's approval was taken.

\section{Conflict of Interest}

No conflict of interest was declared by the authors.

\section{Financial Disclosure}

The authors declared that this study received no financial support.

\section{REFERENCES}

1. Mantas D, Damaskos C, Dailiani P, Samarkos M,Korkolopoulou P. Castleman's disease of the spleen. ActaChirBelg 2016;117:203-8.

2. Casper C. The aetiology and management of Castleman disease at 50 years: translating pathophysiology to patientcare. Br J Haematol 2005;129:3-17.

3. Yi Xie, Yi Zhao, Zhi-Gang Ji, Han-Zhong Li, Guang-Hua Liu, Quan-Zhong Mao. Castleman's Disease: A Rare Mass in the Pararenal Retroperitoneum that Mimics Other Tumors. Chinise medical journal 2017 ;130-17.

4. Bracale U, Pacelli F, Milone M, Bracale UM, Sodo M, Merola G, et al. Laparoscopic treatment of abdominal unicentric Castleman's disease: a case report and literature review. BMC Surg 2017;17:38.

5. El-Osta HE, Kurzrock R. Castleman's disease: from basic mechanisms to molecular therapeutics. Oncologist 2011;16:497-511.

6. Shimokihara et al. Retroperitoneal Castleman's Disease. Case Rep Oncol 2019;12:885-889. 